\title{
PENENTUAN AKTIVITAS EKSTRAK ETANOL CABAI MERAH DALAM MENGHAMBAT PERTUMBUHAN BAKTERI
}

\author{
(THE ABILITY OF RED CHILI ETHANOL EXTRACT \\ IN INHIBITHING THE GROWTH OF BACTERIA)
}

\author{
Alfi Sapitri ${ }^{1}$, Eva Diansari Marbun ${ }^{1}$, dan Ulfayani Mayasari ${ }^{2}$ \\ ${ }^{1}$ Fakultas Farmasi dan Ilmu Kesehatan Universitas Sari Mutiara Indonesia \\ Jl. Kapten Muslim No.79, Helvetia Tengah, Kota Medan, 20124 \\ ${ }^{2}$ Fakultas Sains dan Teknologi UIN Sumatera Utara Medan Indonesia \\ J1. IAIN No. 1, Medan Timur, Kota Medan, 2023 \\ email: alfi.syahfitri@gmail.com
}

\begin{abstract}
Abstrak
Penelitian ini bertujuan untuk melakukan uji fitokimia terhadap ekstrak etanol Cabai merah (Capsicum annum L.) dan uji aktivitasnya terhadap pertumbuhan bakteri Staphylococcus aureus dan Escherichia coli. Pengujian aktivitas antibakteri ini menggunakan metode difusi agar dengan menggunakan kertas cakram dengan tiga kali pengulangan. Ekstrak etanol cabai merah dibuat dengan konsentrasi 45, 60, 75, dan 90\%. Uji aktivitas antibakteri dilakukan dengan metode Kirby Bauer. Media yang digunakan sebagai uji antibakteri pada penelitian ini yaitu Mueller-Hinton Agar (MHA). Hasil skrining fitokimia terhadap ekstrak etanol cabai merah menunjukkan adanya senyawa metabolit sekunder. Senyawa metabolit sekunder tersebut yaitu alkaloid, flavonoid, tanin, saponin, dan Steroid/triterpenoid. Steroid berfungsi sebagai antimikroba. Hasil penelitian ini juga mengungkapkan adanya kandungan senyawa capsaicin yang terkenal sebagai senyawa aktif antimikroba. Ekstrak etanol cabai merah memiliki aktivitas antibakteri terhadap bakteri Staphylococcus aureus dan Escherichia coli zona bening terendah pada konsentrasi $45 \%$ dan zona bening tertinggi pada konsentrasi $90 \%$. Dapat disimpulkan bahwa ekstrak cabai merah memiliki aktivitas antibakteri terhadap penghambatan pertumbuhan bakteri.

Kata kunci: ekstrak etanol, Capsicum annum L, Staphyloccocus aureus, Escherichia coli
\end{abstract}

\begin{abstract}
This study aimed to perform a phytochemical test on the ethanolic extract of red chili (Capsicum annum L.) and test its activity against the growth of Staphylococcus aureus and Escherichia coli bacteria. This antibacterial activity test used the agar diffusion method using disc paper with three repetitions. Red chili ethanol extract was made with concentrations of $45 \%, 60 \%$, $75 \%$ and $90 \%$. The antibacterial activity test was carried out using the Kirby Bauer method. The medium used as an antibacterial test in this study was Mueller-Hinton Agar (MHA). The results of phytochemical screening of red chili ethanol extract showed the presence of secondary metabolites. The secondary metabolites are alkaloids, flavonoids, tannins, saponins, and steroids/triterpenoids. Steroids serve as antimicrobials. The results of this study also revealed the presence of capsaicin compounds which are known as active antimicrobial compounds. Red chili ethanol extract had antibacterial activity against Staphylococcus aureus and Escherichia coli bacteria in the lowest clear zone at a concentration of $45 \%$ and the highest clear zone at a concentration of $90 \%$. It can be concluded that red chili extract has antibacterial activity against bacterial growth inhibition.
\end{abstract}

Keywords: ethanol extract, Capsicum annum L., Staphyloccocus aureus, Escherichia coli 


\section{PENDAHULUAN}

Pemakaian tanaman obat cenderung meningkat pada saat ini. Biasanya, tanaman obat yang dipergunakan berbentuk simplisia. Simplisia tersebut berasal dari akar, daun, bunga, biji, buah, terna, dan kulit batang (Purwanto, 2016, p. 12). Penggunaan tanaman sebagai obat perlu ditingkatkan, sebagai salah satu alternatif pengobatan. Selain harganya relatif murah, tidak memiliki efek samping jika penggunaannya sesuai aturan dan tingkat bahannya yang jauh lebih rendah dibandingkan dengan obat kimia (Susetya, 2012).

Cabai merah (Capicum annum L.) merupakan komoditas hortikultura yang penting bagi kebutuhan konsumsi manusia. Cabai sangat bermanfaat untuk berbagai keperluan, baik yang berhubungan dengan kegiatan rumah tangga maupun untuk keperluan lain seperti untuk bahan ramuan obat tradisional, bahan makanan serta industri (Nurahmi et al., 2011).

Rahim dkk. (2014) menyatakan bahwa ekstrak cabai rawit yang juga memiliki kandungan serupa dengan cabai merah, memiliki diameter daya hambat terhadap bakteri Staphylococcus aureus pada konsentrasi maksimum 100\% sebesar 10,8 $\mathrm{mm}$. Ekstrak cabai rawit dapat menghambat pertumbuhan bakteri Escherichia coli pada konsentrasi minimum $25 \%$ dengan diameter daya hambat sebesar $8,0 \mathrm{~mm}$ dan konsentrasi maksimum $100 \%$ memiliki diameter daya hambat sebesar 11,2 mm (Lestari dkk., 2016). Gayathri et al. (2016) menyatakan bahwa ekstrak cabai gendol atau cabai gendot pada konsentrasi $60 \%$ memiliki diameter daya hambat terhadap bakteri Staphylococcus aureus sebesar $21 \mathrm{~mm}$, dan pada Escherichia coli sebesar $14 \mathrm{~mm}$.

Berdasarkan latar belakang di atas, pada penelitian ini dilakukan uji fitokimia terhadap ekstrak etanol Cabai merah (Capsicum annum L.) dan uji aktivitasnya terhadap pertumbuhan bakteri Staphylococcus aureus dan Escherichia coli.

\section{METODE}

Penelitian ini dilakukan dengan menggunakan metode eksperimental dengan tahapan-tahapan penelitian yaitu pengumpulan dan pengolahan bahan, identifikasi tumbuhan, pembuatan ekstrak etanol cabai merah (Capsicum annum L.), pembuatan larutan pereaksi, skrining fitokimia dan pengujian aktivitas antibakteri dengan metode difusi agar menggunakan kertas cakram terhadap bakteri Staphylococcus aureus (ATCC 25923) dan Escherichia coli (ATCC 25922).

Alat-alat yang digunakan dalam penelitian ini adalah aluminium foil, autoklaf, batang pengaduk, beaker glass, kertas saring whatman, timbangan analitik, mikropipet, cawan petri, gelas beker, erlenmeyer, 
aluminium foil, batang pengaduk, benang wol, jangka sorong, jarum ose, bunsen, kapas, penangas air, kertas cakram, pinset, inkubator, gelas ukur, cawan porselin, kertas perkamen, rotary evaporator, pipet tetes, toples kaca, tabung reaksi, mikroskop, gelas ukur, dan Laminar Air Flow.

Bahan yang digunakan dalam penelitian ini adalah ekstrak cabai merah (Capsicum annum L.), Aquadest, DMSO (Dymetil sulfoxide), kloramfenikol, Etanol 96\%, $\mathrm{NaCl}$ 0,9 \%, Nutrient agar (NA), Larutan Mc Farland, Media Mueller Hinton Agar (MHA). Pereaksi Mayer, Pereaksi Bouchardart, Pereaksi Dragendroff, Besi (III), dan Kloralhidrat.

Alat-alat yang digunakan dalam uji daya hambat antibakteri ini, disterilkan terlebih dahulu sebelum dipakai. Alat-alat gelas disterilkan di dalam oven pada suhu $170^{\circ} \mathrm{C}$ selama 2 jam. Media disterilkan di autoklaf pada suhu $121^{\circ} \mathrm{C}$ selama $15-20$ menit. Jarum ose dan pinset dengan lampu Bunsen (Dima dkk., 2016)

Serbuk simplisia diekstraksi dengan cara maserasi dengan menggunakan pelarut etanol 96\%. Etanol umum digunakan sebagai pelarut karena lebih selektif, kapang dan kuman sulit tumbuh dalam konsentrasi alkohol lebih dari $20 \%$ sehingga dapat mencegah tumbuhnya jamur pada ekstrak (Kusumawati dkk., 2017). Simplisia cabai merah ditimbang sebanyak $500 \mathrm{~g}$ dimasukkan ke dalam toples kaca dan diekstraksi dengan pelarut etanol 96\%. Ekstrak yang didapat kemudian diuapkan dengan menggunakan rotary evaporator pada suhu $50^{\circ} \mathrm{C}$ sampai diperoleh ekstrak kental (Ditjen POM, 1979). Karakterisasi Serbuk dan skrining fitokimia dilakukan terhadap ekstrak etanol cabe merah.

Variasi konsentrasi ekstrak cabai merah (Capsicum annum L.) dibuat dengan melarutkan ekstrak dengan DMSO dengan konsentrasi 45, 60, 75, dan 90\%. Kemudian dilakukan uji aktivitas antibakteri ekstrak cabai merah terhadap Staphylococcus aureus dan Esherichia coli. Uji aktiaktivitas antibakteri dilakukan dengan metode Kirby Bauer.

\section{HASIL DAN PEMBAHASAN}

Skiring Fitokimia terhadap ektrak cabai merah meliputi pemeriksaan alkaloid, flavonoid, tanin, saponin dan steroid/ triterpenoid. Hasil uji fitokimia pada ekstrak etanol cabe merah disajikan pada Tabel 1.

Pada pemeriksaan alkaloid, serbuk simplisia, ekstrak etanol cabai merah, dengan penambahan pereaksi mayer akan terbentuk endapan putih/kuning, pada penambahan pereaksi bouchardat akan terbentuk endapan coklat hitam, pada penambahan pereaksi dragendroff akan terbentuk endapan merah bata. Pada pemeriksaan flavonoid dengan penambahan serbuk Mg dan asam klorida 
Penentuan Aktivitas Ekstrak Etanol (Sapitri, A., Marbun, E. D., \& Mayasari, U.)

Tabel 1

Skrining Fitokimia Cabai Merah

\begin{tabular}{cllcl}
\hline No & Senyawa & \multicolumn{1}{c}{ Pereaksi } & $\begin{array}{c}\text { Ekstrak } \\
\text { Cabai Merah }\end{array}$ & \multicolumn{1}{c}{$\begin{array}{c}\text { Perubahan } \\
\text { yang Terjadi }\end{array}$} \\
\hline 1 & Alkaloid & Mayer & + & Endapan putih/ kuning \\
& & Bouchardat & + & Endapan coklat hitam \\
& & Dragendroff & + & Endapan merah bata \\
2 & Flavonoid & $\mathrm{Mg}+\mathrm{HCl}(\mathrm{p})$ & + & Larutan warna merah/kuning \\
3 & Tanin & $\mathrm{FeC131 \%}$ & + & $\begin{array}{l}\text { Larutan warna biru/hijau } \\
\text { kehitaman }\end{array}$ \\
& & & & Terbentuk busa setinggi 1-10 \\
4 & Saponin & Aquadest $+\mathrm{HC1} 2 \mathrm{~N}$ & + & \\
& & & & cm. \\
5 & Steroid/Tri & n-heksan, $(\mathrm{CH} 3 \mathrm{C} 0) 20$, & + & Merah jingga/Hijau \\
& terpenoid & H2SO4(P) & & \\
\hline
\end{tabular}

Keterangan: $(+)=$ Menunjukkan adanya golongan senyawa, sedangkan. $(-)=$ Menunjukkan tidak adanya golongan senyawa

akan menghasilkan warna merah/kuning. Pada pemeriksaan tanin dengan penambahan $\mathrm{FeC1}_{3} 1 \%$ akan menghasilkan warna biru/ hijau kehitaman. Pada pemeriksaan saponin dengan penambahan aquadest panas, didinginkan kemudian dikocok kuat-kuat selama 10 detik akan timbuk busa setinggi 1-10 $\mathrm{cm}$ yang stabil tidak kurang dari 10 menit dan tidak hilang dengan penambahan HC1 2N dan pada pemeriksaan steroid/ triterpenoid dengan penambahan asam asetat anhidrat dan asam sulfat pekat. Timbul warna ungu/merah berarti positif terpenoid dan warna hijau/biru menandakan positif steroid (Ditjen POM, 1995).

Penetapan kadar air pada simplisia (Tabel 2) dilakukkan untuk mengetahui jumlah air yang terkandung dalam simplisia yang digunakan. Kadar air simlisia ditetapkan untuk menjaga kualitas simplisia karena kadar air berkaitan dengan kemungkinan pertumbuhan jamur atau kapang. Hasil penetapan kadar air diperoleh lebih kecil dari $10 \%$ yaitu $6,99 \%$

Tabel 2

Hasil Pemeriksaan Karakterisasi Serbuk Simplisia Cabai Merah

\begin{tabular}{clcc}
\hline No & \multicolumn{1}{c}{ Parameter } & Hasil \% & Refrensi (FHI) \\
\hline 1 & Kadar air & $6,99 \%$ & $<10 \%$ \\
2 & Kadar sari larut air & $8,43 \%$ & $>7 \%$ \\
3 & Kadar sari larut etanol & $18,90 \%$ & $>3 \%$ \\
4 & Kadar abu total & $4,08 \%$ & $<15 \%$ \\
5 & Kadar abu tidak larut asam & $0,39 \%$ & $<1 \%$ \\
\hline
\end{tabular}


menunjukkan bahwa simplisia memiliki kadar air yang sulit ditumbuhi jamur dan memenuhi persyaratan dari Farmakope Herbal Indonesia (FHI), kadar air yang lebih $10 \%$ dapat menjadi media yang baik untuk pertumbuhan mikroba, keberadaan jamur atau serangga, serta mendorong kerusakan simplisia (Handoko, 2002).

Penetapan kadar sari dilakukan menggunakan dua pelarut, yaitu air dan etanol. Penetapan kadar sari larut air adalah untuk mengetahui kadar senyawa kimia bersifat polar yang terkandung di dalam simplisia, sedangkan kadar sari larut dalam etanol dilakukkan untuk mengetahui kadar senyawa larut dalam etanol, baik senyawa polar maupun nonpolar (Salni, 2011).

Hasil karakteristik simplisia cabai merah menunjukkan kadar sari yang larut dalam air sebesar $8,43 \%$ sedangkan kadar sari yang larut dalam etanol sebesar 18,90\%, hasil memenuhi persyaratan yang tertera pada FHI sehingga dapat dikatakan untuk mengetahui kandungan senyawa-senyawa aktif yang terkandung didalam simplisia cabai merah menggunakan etanol lebih baik karena etanol memiliki kemampuan menyari dengan polaritas yang lebar mulai dari senyawa nonpolar sampai polar (Saifuddin dkk., 2011).

Penetapan kadar abu total dilakukan dengan tujuan untuk memberikan gambaran kandungan mineral internal dan eksternal yang berasal dari proses awal sampai terbentuknya simplisia. Kadar abu total berkaitan dengan mineral baik senyawa organik maupun anorganik yang diperoleh secara internal maupun eksternal (Depkes RI, 2000, pp. 1-19). Kadar abu tidak larut asam untuk menunjukkan jumlah silikat, khususnya pasir yang ada pada simplisia dengan cara melarutkan abu total dalam asam klorida (Sari dkk., 2013). Penetapan kadar abu total sebesar 4,08\% dan kadar abu tidak larut asam sebesar $0,39 \%$. Kadar abu total dan abu tidak larut asam pada simplia memenuhi persyaratan yang tertera pada FHI sehingga dapat dikatakan kadar pencemaran logam pada simplisia cabai merah memenuhi persyaratan sebagai simplisia yang baik (Depkes RI, 1995).

Penelitian yang dilakukan mengenai uji aktivitas antibakteri ekstrak etanol cabai merah terhadap Staphylococcus aureus dan Escherichia coli dilakukan dengan metode difusi agar menggunakan kertas cakram dengan menggunakan media Mueller Hinton Agar (MHA). Hasil pengukuran diameter zona hambat disajikan pada Tabel 3 dan 4.

Hasil pengukuran aktivitas antibakteri ekstrak cabai merah terhadap Staphylococcus aureus dan Escherichia coli ditunjukkan dengan adanya zona hambat berupa zona bening disekitar kertas cakram yang diukur dengan jangka sorong. Hasil pengujian antibakteri terhadap Staphylococcus aureus 
Penentuan Aktivitas Ekstrak Etanol (Sapitri, A., Marbun, E. D., \& Mayasari, U.)

Tabel 3

Hasil Zona Hambat Ekstrak Etanol Cabai Merah terhadap Staphylococcus aureus

\begin{tabular}{|c|c|c|c|c|c|}
\hline \multirow[t]{2}{*}{ Sampel } & \multirow[t]{2}{*}{ Konsentrasi } & \multicolumn{3}{|c|}{$\begin{array}{l}\text { Diameter Zona } \\
\text { Hambat }(\mathrm{mm})\end{array}$} & \multirow{2}{*}{$\begin{array}{l}\text { Zona Hambat } \\
\text { Rata-Rata } \\
(\mathrm{mm}) \& \text { SD }\end{array}$} \\
\hline & & P1 & P2 & P3 & \\
\hline \multirow{4}{*}{$\begin{array}{l}\text { Ekstrak Etanol } \\
\text { Cabai merah }\end{array}$} & $45 \%$ & 9,1 & 8,7 & 8,3 & $8,7 \pm 0,4$ \\
\hline & $60 \%$ & 11,1 & 10,9 & 10,4 & $10,8 \pm 0,36$ \\
\hline & $75 \%$ & 14,1 & 12,9 & 13,7 & $13,56 \pm 0.61$ \\
\hline & $90 \%$ & 17 & 15,8 & 16,8 & $16.53 \pm 0.64$ \\
\hline Kloramfenikol (+) & 31,5 & & & & $31,5 \pm 0$ \\
\hline Aquadest (-) & & 0 & & & 0 \\
\hline
\end{tabular}

Tabel 4

Hasil Zona Hambat Ekstrak Etanol Cabai Merah terhadap Pertumbuhan Escherichia coli

\begin{tabular}{|c|c|c|c|c|c|}
\hline \multirow{2}{*}{ Sampel } & \multirow{2}{*}{ Konsentrasi } & \multicolumn{3}{|c|}{$\begin{array}{l}\text { Diameter Zona } \\
\text { Hambat }(\mathrm{mm})\end{array}$} & \multirow{2}{*}{$\begin{array}{l}\text { Zona Hambat Rata- } \\
\text { rata }(\mathrm{mm}) \& \mathrm{SD}\end{array}$} \\
\hline & & P1 & $\mathrm{P} 2$ & P3 & \\
\hline \multirow[t]{4}{*}{ Cabai merah } & $45 \%$ & 9,8 & 9,2 & 9,1 & $9,3 \pm 0,38$ \\
\hline & $60 \%$ & 10,2 & 10,3 & 10,7 & $10,4 \pm 0,26$ \\
\hline & $75 \%$ & 11,4 & 12,7 & 12,2 & $12,1 \pm 0,66$ \\
\hline & $90 \%$ & 14,1 & 15,3 & 14,2 & $14,5 \pm 0,66$ \\
\hline Kloramfenikol (+) & & 28,5 & & & $28,5 \pm 0$ \\
\hline Aquadest(-) & & 0 & & & 0 \\
\hline
\end{tabular}

disajikan pada Tabel 3. Konsentrasi terkecil (45\%) dengan diameter zona hambat sebesar $8,7 \mathrm{~mm}$ termasuk dalam respon hambatan sedang dan untuk konsentrasi terbesar (90\%) dengan zona hambat sebesar 16,53 $\mathrm{mm}$ termasuk respon hambatan kuat. Hal ini menunjukan bahwa tingkat penghambatan pertumbuhan bakteri Staphylococcus aureus oleh ekstrak cabai merah mengalami kenaikan dari konsentrasi $45 \%$ sampai $90 \%$. Zona hambat efektif pada konsentrasi $75 \%$ sebesar 13,56 mm dan 90\% sebesar 16,53 mm. Hal ini sesuai dengan Farmakope
Indonesia Edisi IV tentang penetapan potensi antibiotika secara mikrobiologi menghasilkan batas daerah hambat dinilai efektif apabila memiliki diameter daya hambat lebih kurang $14 \mathrm{~mm}$ sampai $16 \mathrm{~mm}$ (Ditjen POM, 1995).

Hasil dari data uji aktivitas ekstrak etanol cabai merah terhadap Staphylococcus aureus kemudian dilakukan uji analisa statistik dengan menggunakan uji anova sebelum dilakukan uji anova data harus dilakukan uji normalitas kepada seluruh konsentrasi ekstrak etanol terhadap 
Staphylococcus aureus berdistribusi normal dengan nilai signifikan $0,000>\alpha=0,05$. Semua data berdistribusi normal, maka dilakukan uji Anova untuk melihat pengaruh ekstrak etanol cabai merah terhadap Staphylococcus aureus. Berdasarkan hasil uji anova diperoleh bahwa nilai signifikan perlakuan terhadap diameter zona hambat Staphylococcus aureus diperoleh nilai signifikansi $0,000<\alpha=0,05$.

Hasil pengujian antibakteri terhadap Escherichia coli dapat ditunjukkan pada Tabel 4. Konsentrasi terkecil (45\%) dengan diameter zona hambat sebesar 9,3 $\mathrm{mm}$ dalam respon hambatan sedang dan untuk konsentrasi terbesar $(90 \%)$ dengan diameter zona hambat sebesar $14,5 \mathrm{~mm}$ termasuk respon hambatan kuat. Hal ini menunjukkan bahwa tingkat penghambatan pertumbuhan bakteri Escherichia coli oleh ektrak cabai merah mengalami kenaikan dari konsentrasi $45 \%$ sampai $90 \%$ dan zona hambat yang efektif berada di konsnetrasi $90 \%$ sebesar 14,5 $\mathrm{mm}$ hal ini sesuai dengan Farmakope Indonesia Edisi IV batas nilai hambat dinilai efektif apabila memiliki diameter daya hambat lebih kurang $14 \mathrm{~mm}$ sampai $16 \mathrm{~mm}$ (Ditjen POM, 1995). Hasil ini menunjukkan bahwa ukuran zona hambat yang terbentuk berbeda-beda pada konsentrasi. Semakin tinggi konsentrasi ekstrak cabai merah, maka semakin besar zona hambat yang terbentuk. Begitu juga sebaliknya, semakin rendah konsentrasi ekstrak maka semakin kecil zona hambat yang terbentuk. Hal ini dikarenakan pengaruh oleh besar kecilnya konsentrasi atau kandungan zat aktif yang terkandung di dalamnya serta kecepatan difusi bahan aktibakteri kedalam medium agar. Ekstrak etanol cabai merah memiliki senyawa metabolit sekunder yang terdiri dari alkaloid, flavonoid, tanin, saponin, steroid/ triterpernoid yang bekerja sebagai antibakteri. Selain lima kandungan senyawa di atas, kandungan capsaicin yang terkandung dalam cabai merah yang merupakan senyawa fenol yang bertanggung jawab terhadap rasa pedas pada cabai. Selain itu, capsaicin juga terkenal sebagai senyawa aktif antimikroba (penghambat pertumbuhan mikroorganisme). Mekanisme capsaisin dalam menghambat mikorganisme dimulai dengan penetrasi capsaicin kedalam sel mikroba, kemudia akan menghambat sintesi protein serta merusak DNA (Maharani \& Warsiki, 2014).

Hasil dari data uji Anava ekstrak etanol cabai merah terhadap Escherichia coli bahwa seluruh konsentrasi berdistribusi normal dengan nilai signifikan $0,000>\alpha=$ 0,05 . Kemudian dilanjutkan uji Anava untuk melihat pengaruh ekstrak etanol cabai merah terhadap Escherichia coli. Berdasarkan hasil uji Anava diperoleh bahwa nilai signifikan perlakuan terhadap diameter zona hambat Escherichia coli diperoleh nilai signifikansi $0,000<\alpha=0,05$. 
Pengukuran hasil penelitian dengan zona hambat ekstrak etanol cabai merah yang telah dibuat konsentrasi $45,60,75$, dan $90 \%$, terhadap bakteri Escherichia coli dan Staphylococcus aureus terlihat daerah bening disekitar kertas cakram (Paper disk). Hasil dari penelitian ini menunjukan bahwa zona hambat dari ekstrak etanol cabai merah semakin tinggi konsentrasi maka zona hambatnya semakin besar dari konsentrasi 45 sampai $90 \%$. Hal ini sesuai dengan Pelczar dan Chan (1986) menyatakan semakin tinggi konsentrasi ekstrak maka senyawa aktif antimikroba yang terkandung makin banyak sehingga kemampuan untuk menghambat pertumbuhan mikroba semakin tinggi pula.

Pada bakteri Escherichia coli dan Staphylococcus aureus terdapat perbedaan hasil dari pengukuran zona bening pada masing-masing kelompok perlakuan disebabkan beberapa faktor antara lain jenis bakteri yang dipakai yaitu Escherichia coli tergolong bakteri gram negatif dan Staphylococcus aureus adalah golongan bakteri gram positif. Zona hambat yang terbentuk pada bakteri Staphylococcus aureus lebih besar dari pada Escherichia coli. Hal ini sesuai penelitian Lestari dkk. (2016) yang menyatakan beberapa faktor-faktor yang dapat mempengaruhi terbentuknya zona hambat adalah kepekaan pertumbuhan bakteri, reaksi antara bahan aktif denga medium dan suhu inkubasi.
Perbedaan hasil zona bening disekitar cakram pada kedua bakteri terlihat berbeda dikarenakan adanya kepekaan yang berbeda antara bakteri Gram negatif dan bakteri Gram positif. Radji (2013) menyatakan bahwa jenis bakteri gram positif memiliki struktur dinding sel yang lebih sederhana dibandingkan dengan bakteri gram negatif memiliki kandungan lemak yang relatif lebih tinggi sehingga lebih tahan terhadap perubahan lingkungan yang disebabkan oleh bahan kimia. Hal inilah yang diduga mengakibatkan dinding sel bakteri gram positif mudah rusak oleh senyawa antibakteri dan ekstrak etanol cabai merah dari pada gram negatif.

Perbedaan aktivitas antibakteri Staphylococcus aureus dan Escherichia coli diduga disebabkan oleh penggunaan jenis pelarut etanol karena bersifat polar. Naufalin dkk. (2009) menyatakan bahwa ekstrak etanol (polar) buah cabai merah menghasilkan komponen alkaloid, flavonoid, saponin, tannin, steroid/triterpenoid. Komponen fitokima yang terlarut dalam pelarut polar inilah yang menyebabkan ekstrak etanol cabai merah memiliki daya hambat yang berbeda dan lebih besar pengaruhnya terhadap bakteri Staphylococcus aureus. Berdasarkan penelitian yang dilakukan oleh Qomar dkk. (2018) mengenai ekstrak daun kayu manis terhadap Staphylococcus epidermidis memiliki zat yang memberikan 
efek antimikroba seperti minyak atsiri, flavonoid, saponin, tanin, dan alkaloid. Hal ini juga didukung oleh pendapat Ningtyas (2010) yang menyatakan bahwa senyawa yang bersifat polar sukar untuk melalui dinding sel gram negatif karena kandungan dinding sel bakteri gram negatif lebih banyak dari pada sel bakteri gram positif. Kontrol positif yang digunakan yaitu kloramfenikol. Mekanisme kerja kloramfenikol dalam menghambat pertumbuhan bakteri adalah dengan menghambat sintesis protein yang kuat pada mikroorganisme dan antibakteri yang berisifat bakteristatik dan berspektrum luas. Obat ini menghalangi pelekatan asam amino pada rantai peptida yang baru timbul pada unit 50S pada ribosom, dengan mengganggu daya kerja peptidil transferase (Brooks dkk., 2013). Hasil penelitian Lestari dkk. (2016) pada ekstrak daun cabe rawit (Capsicum frutescens L.) memiliki aktivitas antibakteri terhadap penghambatan pertumbuhan bakteri Escherichia coli pada konsentrasi $25 \%, 50 \%, 75 \%$, dan $100 \%$ memiliki daya hambat masing-masing 8,0 ; 9,$1 ; 10,1$; dan $11,2 \mathrm{~mm}$.

\section{SIMPULAN}

Hasil skrining fitokimia terhadap ekstrak etanol cabai merah menunjukkan adanya senyawa metabolit sekunder yaitu alkaloid, flavonoid, tanin, saponin, dan Steroid/triterpenoid sebagai antimikroba serta kandungan senyawa capsaicin yang terkenal sebagai senyawa aktif antimikroba. Ekstrak etanol cabai merah memikili aktivitas antibakteri terhadap bakteri Staphylococcus aureus dan Escherichia coli zona bening terendah pada konsentrasi $45 \%$ dan zona bening tertinggi pada konsentrasi $90 \%$.

\section{DAFTAR PUSTAKA}

Brooks, G. F., Butel, J. S., Morse, S. A., \& Mudihardi, E. (2013). Jawetz, Melnick, \& Adelberg's mikrobiologi kedokteran. (Aryadhito Widhi Nugroho dkk., Terj.). Salemba Medika.

Depkes RI. (1995). Materia medika Indonesia (Jilid VI). Departemen Kesehatan RI.

Depkes RI. (2000). Parameter standar umum ekstrak tumbuhan obat (Cetakan Pertama). Departemen Kesehat-an RI.

Dima, L. L. R. H., Fatimawali, \& Lolo, W. A. (2016). Uji aktivitas antibakteri ekstrak daun kelor (Moringa oleifera L.) terhadap bakteri Escherichia coli dan Staphylococcus aureus. Pharmacon Jurnal Ilmiah Farmasi, 5(2), 282-289.

Ditjen POM RI. (1995). Farmakope Indonesia (Edisi IV). Departemen Kesehatan RI.

Gayathri, N., Gopalakrishnan, M., \& Sekar, T. (2016). Phytochemical screening and antimicrobial activity of Capsicum chinense Jacq. International Journal of Advances in Pharmaceutics, 5(1), 12-20.

Handoko, C. (2002). Pengaruh naungan terhadap pertumbuhan, produksi dan mutu bangle (Zingiber purpureum Roxb.) pada beberapa taraf pemupukan nitrogen (Skripsi tidak diterbitkan). Institut Pertanian Bogor, Bogor.

Kusumawati, E., Apriliana, A., \& Khatimah, K. (2017). Uji aktivitas antibakteri 
ekstrak etanol daun kerehau (Callicarpa longifolia Lam) terhadap Escherichia coli dan Staphylococcus aureus. Jurnal Ilmiah Manuntung, 2(2), 166-172.

Lestari, A. P., Rosyid, A., \& Wahyudin, I. (2016). Aktivita ekstrak cabe rawit (Capsi.sum annum L.) terhadap penghambatan pertumbuhan bakteri Echerchia coli secara invitro. Jurnal Farmasi Sains dan Praktis, 1(2), 1-6.

Maharani, U., \& Warsiki, E. (2014). Pemanfaatan oleoresin cabai untuk film antimikroba penghambat pertumbuhan Escherichia coli (Skripsi tidak diterbitkan). IPB, Bogor.

Naufalin, R., H. S. Rukmini, T. Yanto, \& Erminawati. (2009). Formulasi dan produksi pengawet alami dari kecombrang (Nicolaia speciosa Horan) (Laporan Penelitian Hibah Kompetensi). Direktorat Jenderal Pendidikan Tinggi.

Ningtyas, R. (2010). Uji antioksidan antibakteriekstrakair daun kecombrang (Etlingera elation (Jack.) R. M, Smith) sebagai pengawet alami terhadap Escherichia coli dan Staphylococcus aureus (Skripsi tidak diterbitkan). Fakultas Sains dan Teknologi Universita Islam Negeri Syarif Hidayatullah, Jakarta.

Nurahmi, E., Mahmud, T., \& Sylvia, R., S. (2011). Efektivitas pupuk organik terhadap pertumbuhan dan hasil cabai merah. Jurnal Floratek, 6(1), 158-164.

Pelczar, M. J., \& Chan, E. C. S. (1986). Dasar-dasar mikrobiologi. UI-Press.
Purwanto, Ns. B. (2016). Obat herbal andalan keluarga. Flashbook.

Qomar, M. S., Budiyanto, M. A. K., Sukarsono, S., Wahyuni, S., \& Husamah, H. (2018). Efektivitas berbagai konsentrasi ekstrak daun kayu manis (Cinnamomum burmannii [Ness.] BI) terhadap diameter zona hambat pertumbuhan bakteri Staphylococcus epidermidis. Jurnal Biota, 4(1), 12-18.

Radji, M. (2013). Buku ajar mikrobiologi panduan mahasiswa farmasi \& kedokteran. Kedokteran EGC.

Rahim, A., Wahyudin, I., Lusyana, E., Aprilianti, E., Shofa, Z. N., Widyaningrum, N., \& Sari, N. P. (2014). Efektifitas antibakteri ekstrak cabe rawit (Capsium annum L.) terhadap bakteri Staphylococcus aureus dengan metode difusi uji pendahuluan potensi tanaman obat tradisional sebagai alternatif pengobatan saluran pernafasan. Prosiding SNST ke-5, 1(1), 7-12.

Saifuddin, A., Teruna, H. Y., \& Rahayu, V. (2011). Standarisasi bahan obat alam. Graha Ilmu.

Sari, D. L. N., Cahyono, B., \& Kumoro, A. C. (2013). Pengaruh jenis pelarut pada ekstraksi Kurkuminoid dari rimpang Temulawak (Curcuma xanthorrhiza Roxb). Jurnal Chem Info, 1(1), 101107.

Susetya, D. (2012). Khasiat \& manfaat daun ajaib binahong. Pustaka Baru Press. 